\title{
PERSONAL SAFETY. PROTECTION OF THE VICTIMS OF CRIME
}

\section{S-A. COVALCIUC}

\section{Sorina-Alexandra COVALCIUC}

Faculty of Law and Administrative Sciences, European Law Department

"Ștefan cel Mare" University of Suceava, România

E-mail: covalciucalexandra@gmail.com

\section{ABSTRACT:}

The impact of the crime phenomenon on the persons affected by it can be a profound one transposed into physical, mental, emotional and financial injuries, of which some victims can never recover. The actions that make up the criminal act can be harmed on the victims, witnesses or their families, and the most serious of the threats are those against the person's life. The paper focuses, first and foremost, on the measures to be taken to protect the victims of crime, as well as on the means of support offered to the victims so that they can enjoy the right of access to justice in order to cover their harm.

KEY WORDS: victims of crime, protection of victims of crime, access to justice, compensation for victims of crime

\section{INTRODUCTION}

Every year, about $15 \%$ of the European population or 75,000 people in the European Union are charged as victims of crime ${ }^{1}$. This fact shows us that some protection measures are necessary to adopt in favour of victims or possible victims of crimes (and a relative of the main protected person), in criminal matters, taking into appropriate consideration to the needs of victims, including particularly vulnerable persons (e.g. minors, person with disablities). However, it should not apply to measures adopted with a view to witness protection.

The United Nations Declaration on the Basic Principles for Victims of Crime and Abuse of Power (1985) defines the term victim as those people who, individually or collectively, suffered any harm, physical or mental, emotional experiences, economic losses or the material injury of their fundamental rights, by action or inaction that violates the criminal law in force, within the Member States, including those laws that stipulate the illicit abuse of power. The person is considered a victim whether the perpetrator is identified, arrested, investigated or convicted and, regardless of the relationship between the perpetrator and the victim.

By the term injured person in Romanian law we understand the person who suffered an injury of his interests or rights by an anti-social deed committed against her. That person has this quality as long as the prosecution has not begun. In the criminal trial the victim can be constituted:

- The injured party, as a person who suffered through the criminal act a physical, moral or material injury and participates in the criminal process;

\footnotetext{
1 See Victim's rights, Suport and protection of victims, https://ec.europa.eu/info/policies/justice-andfundamental-rights/criminal-justice/victims-rights en, accesed on 8.11.2019.
} 


\section{Sorina-Alexandra Covalciuc}

- Civil party, designating the injured person who exercises the civil action in the criminal trial;

- Witness, if it is not a civil party or does not participate in the trial as an injured party. In this quality, the person can be heard with a protected identity, when there is good evidence or evidence that his or her life, bodily integrity or freedom could be endangered.

The victim's statement is a means of proof and can be used to find out the truth, in conjunction with the other means of proof. Also during the criminal trial the victim is questioned regarding the material and moral damages suffered, in order to solve the civil side of the case.

On the one hand, the problem that arises is that some crimes are not reported in official statistics - rape is an example - but they can be revealed in some surveys. However, just as those arrested or who admit to committing the crime are not necessarily all the offenders, those who report being victims of the crime are not necessarily typical of the whole range of victims.

However, some basic facts gathered from the official reports and from the surveys attributed to the victims, offer a reasonable portrayal of the victims of the crime. Most of the times, the groups that are most likely to be victims of the crime are the same groups that are most likely to commit the crime. In particular, victims of crime can be young people, people from a lower socioeconomic class and members of ethnic or racial minority groups ${ }^{2}$.

On the other hand, another important issue is the fact that both victims of crime and witnesses of serious crimes are reluctant to provide information and investigation bodies because of apparent or real intimidation or threats against them or their family members. In this case, it is essential to analyze the needs of the victims, which vary from victim to victim. In this way, we can say that a certain type of crime gives rise to special needs and specific problems that are correlated with the type and nature of that crime. These needs and problems may be different or may resemble those of other victims ${ }^{3}$.

Also, the victims do not have knowledge, information regarding the applicable judicial and administrative procedures, which is why they may be reluctant when identified by the criminal prosecution bodies. Moreover, as a result of the multiple abuses suffered and the complex consequences on their psyche, victims may show distrust in working with the police or other authorities.

Moreover, the victim's cooperation with the justice will be effective only when the internal obstacles, but also the pressures, threats and risks to which she is exposed will be eliminated, ensuring her full physical and social protection, guaranteeing her fundamental rights.

Each victim must be treated individually to meet their needs, and yet we can categorize the needs into five broad categories:

- respect and recognition;

- protection against intimidation, repression and subsequent injury by the suspect or defendant and against injury during criminal investigations and judicial proceedings;

- immediate assistance after the crime, as well as long-term physical and psychological assistance;

\footnotetext{
${ }^{2}$ Bernard J. Thomas, Thomas A. David, Characteristics of victims, https://www.britannica.com/topic/crimelaw/Characteristics-of-offenders\#ref932044, accesed on 12.11.2019.

${ }^{3}$ Juncker Jean-Claude, Strengthening victims' rights: from compensation to reparation, Publications Office of the European Union, Luxembourg, 2019, p. 27, https://ec.europa.eu/, accesed on 12.11.2019.
} 
- ensuring access to justice so that victims are aware of their rights and understand them, to be able to participate in proceedings;

- compensation and putting in the previous situation when it is possible, either through financial damages paid by the state or by the offender or through mediation or other form of reparative justice.

\section{THE RIGHTS OF VICTIMS OF CRIME}

The new European Union rules on the rights of victims that apply from 16 November 2015 bring major changes in the way victims of crime are treated in Europe. The Victims Rights Directive establishes a set of mandatory rights for victims and clear obligations for EU Member States to ensure these rights in practice.

The goal is for all victims of crime and their family members to be recognized and treated in a respectful and non-discriminatory manner, based on an individualized approach tailored to the needs of the victim. They change the attitude towards the victims and place the victims in the center of the criminal trial. The rules improve the situation of millions of victims in Europe.

These apply to all persons who are victims of crime in Europe, regardless of their nationality ${ }^{4}$.

\section{Rights of victims' family members}

When victims die as a result of the crime, their family members become victims too. Under the new rules, family members of deceased victims will enjoy the same rights as direct victims, including the right to information, support, protection and compensation. Family members of surviving victims also have the right to support and protection. For example, if a person's husband was killed in a terrorist attack, from that moment on, he or she has exactly the same rights as any other crime victim under the directive, including the right to information, support, protection and compensation.

\section{Right to understand and to be understood}

Under the new rules, all communication with victims must be provided in a simple and accessible language. The form of communication must be adapted to the specific needs of every victim, including, for example, needs related to age, language and any disability.

\section{Right to information}

The new rules require that national authorities give victims a range of information concerning their rights, their case and the services and assistance available to them. For example, they must be informed about the type of support they can obtain, the procedure to make a complaint, how and under what conditions they can obtain protection, legal advice or compensation. The information must be given from the first contact with a competent authority and without delay. If criminal proceedings are launched, victims - if they so wish must be informed about their case including the time and place of the trial, any final judgement or important steps in the case. The victims should also be offered the possibility to receive notification about the release or escape of their offender.

\section{Right to support}

Member States must guarantee that victims have access to support services and must facilitate the referral from authorities to such services. Support must be free of charge and confidential and available also to victims who do not officially report the crime. Support must include both general support services and specialist support services, such as shelters, trauma support and counselling specifically adapted to different types of victims. For example, a girl is a refugee fleeing from Syria. She falls victim to violence in Europe but does not want to

\footnotetext{
${ }^{4}$ Juncker Jean-Claude, Ibid, p. 27.
} 


\section{Sorina-Alexandra Covalciuc}

officially report the crime to the police. A social worker gets into contact with her. The social worker refers her to a specialist support service, where she will find shelter and will receive information, advice and emotional and psychological support ${ }^{5}$.

\section{Right to participate in criminal proceedings}

Victims are entitled to get a more active role in criminal proceedings. They have the right to be heard and be informed about the different steps of the proceedings. In particular, they must be informed if the offender will not be prosecuted and have right to have such a decision reviewed if they do not agree with the decision. They also have the right to compensation and if restorative justice proceedings are used in the national system, there are now safeguards in place to ensure victims' safe participation.

\section{Right to protection and to individual assessment}

Victims must be protected from both the offender and from risk of further harm by the criminal justice system itself. In order to determine their protection needs, all victims must receive an individual assessment to see whether they are vulnerable to further harm that may arise during the criminal proceedings. If so, special protection measures must be put in place to protect them during the proceedings and against any possible threat from the offender. Special attention is given to the protection of children ${ }^{6}$.

\section{Right to compensation}

Another important right that a victim of a crime can claim is to apply to compensate for the damages due to the suffering he went through. All states offer compensation to victims of crime, and the purpose of compensation is to recognize the financial losses of victims and help them recover some of these costs. All states have a ceiling for granting full compensation for each crime. However, most of the time the costs of the crime are not covered. To be eligible for compensation, victims must file a claim, usually over a certain period of time, and show that the losses they claim have occurred without any fault of their own. Some types of losses that are usually covered include: medical and counseling expenses, lost wages, as well as funeral expenses ${ }^{7}$.

\section{COMPENSATION TO VICTIMS OF CRIME}

In European Union, it has adopted several legal instruments, establishing common rules aimed at protecting and supporting victims of crime: horizontal instruments that deal with victims' rights in general, more specific instruments on measures to protect and compensate victims of crime and the instruments of material law regarding the trafficking of human beings and the sexual exploitation of children. A document of major importance in this regard is Directive 2012/29 ${ }^{8}$ of the European Parliament and of the Council of 25 October 2012 establishing minimum standards on the rights, support and protection of victims of crime.

In a common area of justice without internal borders, it is necessary to ensure that the protection provided to a natural person in one Member State is maintained and continued in

\footnotetext{
${ }^{5}$ Jourová Vĕra, The Victims' Rights Directive, Directorate-General for Justice and Consumers, 2017, https://ec.europa.eu, accesed on 12.11.2019.

${ }^{6}$ Jourová Věra, Ibid.

${ }^{7}$ See The National Center for Victims of crime website, https://victimsofcrime.org/help-for-crime-victims/gethelp-bulletins-for-crime-victims/victims'-rights, accesed on 15.11.2019.

${ }^{8}$ Directive 2012/29 / EU replaces the 2001 Framework Decision on the status of victims in criminal proceedings and considerably strengthens the rights of victims and their family members to information, support and protection, as well as procedural rights in criminal proceedings.
} 


\section{PERSONAL SAFETY. PROTECTION OF THE VICTIMS OF CRIME}

any other Member State to which the person moves or has moved. It should also be ensured that the legitimate exercise by citizens of the European Union of their right to move and reside freely within the territory of Member States does not result in loss of their protection?

The Directive applies to protection measures which aim specifically to protect a person against a criminal act of another person, which may, in any way, endanger that person's life or physical, psychological and sexual integrity, dignity or personal liberty and which aim to prevent new criminal acts or to reduce the consequences of previous criminal acts.

The recognition of the European protection order by the Executing State implies inter alia - that the competent authority of that State, subject to the limitations set out in the Directive, accepts the existence and validity of the protection measure adopted in the Issuing State, acknowledges the factual situation described in the European protection order, and agrees that protection should be provided and should continue to be provided in accordance with its national law.

Any request for the issuing of a European protection order should be treated immediately, taking into account the specific circumstances (e.g. urgency, the date of the arrival of the protected person, degree of risk).

The Directive contains an exhaustive list of prohibitions and restrictions which, when imposed in the issuing state and included in the European protection order, they should be recognized and applied in the executing state:

- a prohibition from entering certain localities, places or defined areas where the protected person resides or visits,

- a prohibition or regulation of contact, in any form, with the protected person (by phone, electronic or ordinary mail, fax etc.)

- a prohibition or regulation on approaching the protected person closer than a prescribed distance.

The Directive provides a high degree of flexiblity in the cooperation mechanism between Issuing and Executing States.

In Romania, one stage by which the state approached the victims of the crime was the adoption of law no. 211/2004 regarding some measures to ensure the protection of victims of crime. Thus, the free psychological counseling, upon request, was introduced for:

- the victims of the attempted murder and qualified murder;

- the victims of the crime of domestic violence, provided in art. 199 of the Romanian Criminal Code;

- the victims of the deliberate crimes that resulted in the personal injury of the victim;

- victims of rape, sexual assault, sexual intercourse with a minor and sexual corruption of minors;

- victims of the crime of ill treatment applied to the minor;

- victims of trafficking and exploitation of vulnerable persons and of the attempt on them.

The request for granting free psychological counseling is submitted to the probation service of the court in which the victim's domicile is located.

This request can be filed only after the notification of the criminal prosecution bodies regarding the commission of the crime.

\footnotetext{
${ }^{9}$ Kenéz Andrea, European Union framework for victims' protection in the criminal proceedings. What the judicial practitioner should know?, https://www.ja-sr.sk/, accesed on 15.11.2019.
} 


\section{Sorina-Alexandra Covalciuc}

\section{FINANCIAL COMPENSATION FROM THE STATE}

The financial compensation from the state is a way to compensate for the damage suffered by the victims of certain types of crime in cases where these damages cannot be obtained from the offender.

This can be obtained by the persons on whom one of the following offenses was committed:

- attempted criminal offenses and qualified murder;

- a crime of personal injury;

- $\quad$ an intentional crime that resulted in the bodily injury of the victim;

- a crime of rape, sexual intercourse with a minor or sexual assault;

- a crime of trafficking in persons or trafficking in minors;

- a terrorist offense;

- $\quad$ any other intentional crime committed with violence ${ }^{10}$.

The financial compensation from the state can also be obtained by the spouse, children and persons in the care of the deceased persons by committing the above offenses.

Compensation is granted to the victim only if she has notified the criminal prosecution bodies within 60 days from the date of the offense or, if she was unable to notify the criminal prosecution bodies, within 60 days of on the date when the state of impossibility ceased.

The financial compensation from the state is granted, on the one hand, if the perpetrator is known, if the perpetrator is insolvent or missing, so that no compensation can be obtained from it and the damage was not obtained from either insurance company; and on the other hand, even if the perpetrator is unknown.

During May-June 2018, Romanian Law 211/2004 on some measures to ensure the protection of victims of crime was amended by introducing provisions that will further improve the situation of victims. Among the novelties introduced was the fact that the victim can be accompanied by a person chosen by her in order to facilitate communication with them, on the occasion of first contact with the authorities.

Also, the submission of the complaint according to art. 289 of the Romanian Criminal Procedure Code, the victim will receive a written confirmation thereof. The confirmation will include the registration number of the complaint, as well as data regarding the fact for which the complaint was filed ${ }^{11}$.

If the victim does not speak or understand romanian, he or she may request to receive a written confirmation later.

Moreover, the document regulates the arrangement of separate waiting rooms / spaces for the victims of the crimes, in the headquarters of the courts. A provision has been introduced according to which the judicial bodies have the obligation to inform the victims of the crimes and about:

- the right to call a mediator in cases permitted by law;

- the judicial authority to which they may be addressed in the future for obtaining information on the status of the case, as well as its contact details, if the victim understands to file a complaint.

One year later, the emergency ordinance no. 24/2019 for amending and supplementing Romanian Law no. 211/2004 regarding some measures to ensure the protection of victims of

\footnotetext{
${ }^{10}$ See the Romanian Ministry of Justice website, http://www.just.ro/en/drepturile-victimelor-infractiunilor/, accesed on 17.11.2019.

${ }^{11}$ Hogaş Elena, MEMENTO: Noi măsuri pentru protecţia victimelor infracţiunilor, aplicabile din această lună, iunie 2018, https://legestart.ro/memento-noi-masuri-pentru-protectia-victimelor-infractiunilor-aplicabile-dinaceasta-luna/, accesed on 15.11.2019.
} 


\section{PERSONAL SAFETY. PROTECTION OF THE VICTIMS OF CRIME}

crime, as well as other normative acts was published in the Romanian Official Gazette no. 274 (as of April 10, 2019) and introduced a series of additional protective measures regarding victims of crime.

Among the most important measures newly introduced are those related to the creation of specialized compartments to support the victims of crime or the provisions regarding the supply of individualized services, depending on the victim. The measures will be established both within the general directorate of social assistance and child protection (where there will be psychologists, lawyers and social workers) and within other institutions (for example, in the case of victims of domestic violence, support and protection measures will be granted by institutions specialized in the prevention and combating of domestic violence). In addition, support and protection services can also be provided by private social service providers.

Support and protection services provided to crime victims and their family members can be:

- information on the rights of the victim;

- psychological counseling, counseling on the risks of secondary and repeated victimization or intimidation and retaliation;

- counseling on the financial and practical aspects of the crime;

- social insertion / reintegration services;

- emotional and social support for social reintegration;

- information and advice on the role of the victim in criminal proceedings, including preparation for participation in the trial. These information and counseling services do not include the free legal assistance of victims of crimes provided for in art. 14-20 times the legal assistance of the injured person provided in Romanian Law no. 135/2010 on the Romanian Criminal Procedure Code, with subsequent amendments and completions;

- guiding the victim to other specialized services, when appropriate: social services, medical services, employment services, education services or other services of general interest provided under the law ${ }^{12}$.

As we have stated before, victim evaluation is a very important and preliminary step for these services to be provided according to their needs. The assessments will also be made in order to avoid secondary victimization. Thus, medical / psychological statements or evaluations, for example, will be minimized.

Another example of a protective measure introduced by emergency ordinance no. $24 / 2019$ is the creation of a special register of the victims of the crime who will benefit from the support of the specialized services. That register will be organized at the level of the general directorates of social assistance and child protection.

The register will contain data on victims who benefit from protection and support measures. The respective data will be kept for one year and can be used by the criminal bodies.

\section{CONCLUSIONS}

\footnotetext{
${ }^{12}$ Paragraph (4), article 7 of the Emergency Ordinance of Romanian Government no. 24/2019 for amending and supplementing Law no. 211/2004 regarding some measures to ensure the protection of victims of crime, as well as other normative acts, published in the Official Gazette no. 274/10, Apr. 2009, amended by: L. no.211 / 2004 regarding some measures to ensure the protection of victims of crime, published in the Official Gazette no. 505/4 June. 2004, L. no.192 / 2006 regarding the mediation and organization of the profession of mediator published in the Official Gazette no. 441/22 May. 2006 and L. no.254 / 2013 regarding the execution of the punishments and the deprivation measures of freedom ordered by the judicial bodies during the criminal trial published in the Official Gazette. no. 514/14 Aug. 2013.
} 


\section{Sorina-Alexandra Covalciuc}

Protecting victims is just as important as tracking down terrorists or preventing violence. Caring for victims of violent acts does not just mean fulfilling legal obligations and ensuring the rights of individuals. Caring for victims of violent acts is, above all, a matter of human dignity, respect and solidarity. It is the symbol of a real democracy for which every person counts and deserves to be protected, supported, helped, integrated and reintegrated. The way we treat the victims of crime measures the depth and humanity of our civilization.

\section{BIBLIOGRAPHY}

Bernard J. Thomas, Thomas A. David, Characteristics of victims, https://www.britannica.com/topic/crime-law/Characteristics-of-offenders\#ref932044.

Emergency Ordinance of Romanian Government no. 24/2019 for amending and supplementing Law no. 211/2004 regarding some measures to ensure the protection of victims of crime, as well as other normative acts.

Hogaş Elena, MEMENTO: Noi măsuri pentru protecţia victimelor infracţiunilor, aplicabile din această lună, iunie 2018, https://legestart.ro/memento-noi-masuri-pentru-protectia-victimelorinfractiunilor-aplicabile-din-aceasta-luna/.

Jourová Věra, The Victims' Rights Directive, Directorate-General for Justice and Consumers , February 2017, https://ec.europa.eu.

Juncker Jean-Claude, Strengthening victims' rights: from compensation to reparation, Publications Office of the European Union, Luxembourg, 2019, p. 27, https://ec.europa.eu/.

Kenéz Andrea, European Union framework for victims' protection in the criminal proceedings. What the judicial practitioner should know?, https://www.ja-sr.sk/.

National Center for Victims of crime website, https://victimsofcrime.org/help-for-crimevictims/get-help-bulletins-for-crime-victims/victims'-rights.

Romanian Ministry of Justice website, http://www.just.ro/en/drepturile-victimelorinfractiunilor/.

Victim's rights, Suport and protection of victims, https://ec.europa.eu/info/policies/justice-andfundamental-rights/criminal-justice/victims-rights_en. 